\title{
Effects of Shield1 on the viral replication of varicella-zoster virus containing FKBP-tagged ORF4 and 48
}

\author{
SHUYING LI* ${ }^{*}$ ZHANJUN LIU*, JI LI, AIHUA LIU, LIHUA ZHU, KUI YU and KE ZHANG* \\ School of Basic Medical Sciences, North China University of Science and Technology \\ (Hebei Key Laboratory for Chronic Diseases, Tangshan Key Laboratory for Preclinical and \\ Basic Research on Chronic Diseases), Tangshan, Hebei 063000, P.R. China
}

Received September 13, 2016; Accepted August 2, 2017

DOI: $10.3892 / \mathrm{mmr} .2017 .7986$

\begin{abstract}
The present study aimed to explore the effects of a stabilizing ligand, Shield-1, on the replication of recombinant varicella-zoster virus (VZV) containing FK506 binding protein (FKPB) tags in essential open reading frames (ORF) 4 and 48. A specific galactokinase (galK) selection method was conducted, following the addition of galK labels to VZV ORF4 and 48, using a SW102 VZV bacterial artificial chromosome (BAC) system. Subsequently, recombinant VZV containing FKPB tags in ORF4 and 48 was constructed by counterselection and homologous recombination. Recombinant viral plasmids containing FKPB-tagged VZV ORF4 and 48 were extracted and transfected into human acute retinal pigment epithelial ARPE-19 cells. The results demonstrated that the FKPB-tagged viral protein was rapidly degraded by proteases in recombinant virus-infected ARPE-19 cells. In addition, the recombinant VZVORF4-FKBP-ORF48-FKBP virus could not grow if a synthetic ligand of FKBP, Shield1, was not added to the ARPE-19 cell culture medium; however, the degradation of FKPB-tagged viral protein was prevented if Shield1 was added to the ARPE-19 cell culture medium, thereby allowing viral replication in ARPE-19 cells. These results indicated that Shield1 may regulate replication of recombinant VZVORF4-FKBP-ORF48-FKBP following transfection into human epithelial cells.
\end{abstract}

Correspondence to: Mr. Ke Zhang, School of Basic Medical Sciences, North China University of Science and Technology (Hebei Key Laboratory for Chronic Diseases, Tangshan Key Laboratory for Preclinical and Basic Research on Chronic Diseases), 57 Jianshe South Road, Tangshan, Hebei 063000, P.R. China E-mail: 877567295@qq.com

${ }^{*}$ Contributed equally

Key words: varicella-zoster virus, homologous recombination, Shield1, regulate

\section{Introduction}

Varicella-zoster virus (VZV) is the causative agent of chicken pox and herpes zoster, which is also known as shingles. VZV is a member of the human herpesvirus family and has a $125 \mathrm{~kb}$ double-stranded DNA genome that encodes 70 open reading frames (ORFs), including 44 essential and 26 non-essential ORFs for viral replication (1-7).

In 1974, chickenpox blister fluid was inoculated into primary human embryonic lung cells, and the VZV Oka strain, parent Oka, was isolated by Takahashi et al (8). Subsequently, a live attenuated Oka vaccine (vOka) was successfully obtained following numerous passages in human embryonic lung fibroblasts. While the pathogenicity of vOka was significantly decreased, its immunogenicity remained. The vOka strain is used in VZV vaccines worldwide and is recommended by the World Health Organization; however, it is still likely to cause delayed infection $(9,10)$.

The incidence of chicken pox has decreased since the chicken pox vaccine (vOka strain) was introduced in 1995 (11-13). However, VZV outbreaks still occasionally occur $(14,15)$, and herpes zoster can cause serious harm to patient health. In particular, VZV remains an important pathogenic factor since the current herpes zoster vaccine only reduces the risk of infection by $50 \%$ (16).

Viral proliferation has been analyzed using highly unstable FK506 binding protein (FKBP)12 protein mutants, which rapidly degrade when they are expressed in mammalian cells (17-19). Specifically, recombinant viruses containing the destabilization domain of FKBP tagged to ORFs of interest have been constructed using an FKBP tagged mutant method (20). A synthetic ligand of FKBP, Shield1, can penetrate the cell and stabilize the domain of the FKBP fusion protein. As a result, the recombinant virus can replicate in mammalian cells if Shield1 is added to the mammalian cell culture medium. Conversely, if Shield1 is not added to the mammalian cell culture medium, the FKBP-tagged fusion protein is rapidly degraded, and the recombinant virus does not grow. Accordingly, the FKBP-tagged fusion protein is a powerful genetic tool for studying the role of viral genes and vaccines.

VZV ORF4 encodes transcription factors, whereas VZV ORF48 encodes deoxyribonuclease, which is essential for 
the formation of infectious virus particles (4). In the present study, recombinant VZV containing FKBP-tagged ORF4 and 48 was constructed. The results of the present study indicated that Shield1 can regulate replication of the recombinant virus following its transfection into mammalian cells.

\section{Materials and methods}

Bacterium and plasmids. The following bacterium and plasmids were used in the present study: Escherichia coli SW102 strain, galactokinase (galK) plasmid (pgalK), FKBP plasmid (pFKBP) and SW102 VZV wild-type ( ${ }^{\mathrm{WT}}$ ) bacterial artificial chromosome (BAC) system, which contains the whole VZV WT genome with luciferase and chloramphenicol resistance genes. These plasmids and bacterium were provided by Professor Hua Zhu (New Jersey Medical School, Rutgers University, New Brunswick, NJ, USA).

Media. The following media were generated for use in the present study: i) $1 \mathrm{X}$ M9 medium $(500 \mathrm{ml}): \mathrm{Na}_{2} \mathrm{HPO}_{4}(3 \mathrm{~g})$, $\mathrm{KH}_{2} \mathrm{PO}_{4}(1.5 \mathrm{~g}), \mathrm{NH}_{4} \mathrm{Cl}(0.5 \mathrm{~g})$ and $\mathrm{NaCl}(0.25 \mathrm{~g})$ were dissolved in $\mathrm{ddH}_{2} \mathrm{O}$ to a final volume of $500 \mathrm{ml}$. The medium was then autoclaved. ii) M63 minimal medium (5X M63): $\left(\mathrm{NH}_{4}\right)_{2} \mathrm{SO}_{4}$ $(5 \mathrm{~g}), \mathrm{KH}_{2} \mathrm{PO}_{4}(34 \mathrm{~g})$ and $\mathrm{FeSO}_{4} \cdot 7 \mathrm{H}_{2} \mathrm{O}(1.25 \mathrm{mg})$ were dissolved in $\mathrm{ddH}_{2} \mathrm{O}$ to a final volume of $500 \mathrm{ml}$. The medium was then adjusted to $\mathrm{pH} 7$ with $\mathrm{KOH}$ and was autoclaved. Dulbecco's Modified Eagle's medium (DMEM) with antibiotics (100 U/ml penicillin and streptomycin) and DMEM without antibiotics were also used.

Reagents. Fetal bovine serum, Goldview II nuclear staining dyes and lysogeny broth (LB) were provided by BioTeke Corporation (Beijing, China). Qiagen Multiplex PCR kit, HotStarTaq DNA polymerase, Qiagen Plasmid Mini kits and Qiaquick Gel Extraction kit were provided by Qiagen GmbH (Hilden, Germany). Shield1 was provided by Takara Biotechnology Co., Ltd. (Mountain View, CA, USA).

Plate generation. The following diameter $9 \mathrm{~cm}$ plates were made for use in the present study; i) M63 minimal galK plates: Initially, $7.5 \mathrm{~g}$ agar was added to $400 \mathrm{ml} \mathrm{H}_{2} \mathrm{O}$ and was autoclaved. Subsequently, $100 \mathrm{ml}$ autoclaved 5X M63 medium was added to $0.5 \mathrm{ml} 1 \mathrm{M} \mathrm{MgSO}_{4} \cdot 7 \mathrm{H}_{2} \mathrm{O}$; this mixture was cooled to $50^{\circ} \mathrm{C}$, after which $5 \mathrm{ml} 20 \%$ galactose (sterile) was added as a carbon source, $2.5 \mathrm{ml}$ D-biotin $(0.2 \mathrm{mg} / \mathrm{ml}$, sterile), $2.25 \mathrm{ml}$ L-leucine $(10 \mathrm{mg} / \mathrm{ml}$, sterile) and $500 \mu \mathrm{l}$ chloramphenicol $(12.5 \mathrm{mg} / \mathrm{ml}$, sterile) were also added and mixed. Finally, $\sim 25 \mathrm{ml}$ was poured into each plate. ii) M63 minimal replace galK plates: Initially, $7.5 \mathrm{~g}$ agar was added to $400 \mathrm{ml} \mathrm{H}_{2} \mathrm{O}$ and was autoclaved. Subsequently, $100 \mathrm{ml}$ autoclaved 5X M63 medium was added to $0.5 \mathrm{ml} 1 \mathrm{M} \mathrm{MgSO}_{4} \cdot 7 \mathrm{H}_{2} \mathrm{O}$; this mixture was cooled to $50^{\circ} \mathrm{C}$, after which $5 \mathrm{ml} 20 \%$ 2-deoxy-galactose (sterile), $2.5 \mathrm{ml} \mathrm{D}$-biotin ( $0.2 \mathrm{mg} / \mathrm{ml}$, sterile), $2.25 \mathrm{ml}$ L-leucine (10 mg/ml, sterile), $1.25 \mathrm{ml} 20 \%$ glycerol (autoclaved) and $500 \mu 1$ chloramphenicol $(12.5 \mathrm{mg} / \mathrm{ml}$, sterile) were added and mixed. Finally, $\sim 25 \mathrm{ml}$ was poured into each plate.

Cells. Human acute retinal pigment epithelial (ARPE-19) cells were provided by Professor Hua Zhu (New Jersey Medical School, Rutgers University, New Brunswick, NJ, USA).
Cell culture conditions. ARPE-19 cells were cultivated using $10 \mathrm{ml}$ DMEM with $100 \mathrm{U} / \mathrm{ml}$ Penicillin-Streptomycin and $10 \%$ fetal bovine serum in a diameter $10 \mathrm{~cm}$ petri dish, and were maintained at $37^{\circ} \mathrm{C}$ in a humidified atmosphere of $5 \%$ $\mathrm{CO}_{2} / 95 \%$ air. Cell media was changed every 2-3 days with fresh culture media.

Design and synthesis of primers. The primers for VZV ORF4 and ORF48, which were used in the present study were designed according to the VZV gene sequence provided by GenBank (NCBI Reference Sequence: NC_001348.1; http://www .ncbi.nlm.nih.gov/nuccore/NC_001348). The primers for VZV ORF4 and ORF48 galK, FKBP and Check primers (used for verification plasmids of VZV ORF4 and ORF48 galK, FKBP) are presented in Table I. The primers were synthesized by Sangon Biotech Co., Ltd. (Shanghai, China).

Preparation of SW102 VZV VT BAC electrocompetent cells. SW102 VZV ${ }^{\mathrm{WT}}$ BAC electrocompetent cells were prepared according to a previously described protocol (1), and were stored at $-80^{\circ} \mathrm{C}$.

VZV ORF4 tagged with galK gene. Polymerase chain reaction (PCR) was used to generate the VZV ORF4 galK cassette, as follows: The PCR reaction was conducted in a volume of $100 \mu \mathrm{l}$, containing $1 \mathrm{X}$ PCR buffer, $3.0 \mathrm{mM} \mathrm{MgCl}_{2}, 10 \mu \mathrm{M}$ dNTPs, 4 units HotStarTaq DNA polymerase, $10 \mu \mathrm{M}$ VZV ORF4 galK primer sets (Table I) and 200 ng pgalK DNA (the plasmid DNA was extracted using the Qiagen Plasmid Mini kit (Qiagen $\mathrm{GmbH}$ ), according to manufacturer's protocol), using sterile water as negative control. The PCR cycling conditions were as follows: Denaturation of the template at $95^{\circ} \mathrm{C}$ for $15 \mathrm{~min}$, followed by 31 cycles at $95^{\circ} \mathrm{C}$ for $30 \mathrm{sec}, 55^{\circ} \mathrm{C}$ for $30 \mathrm{sec}$ and $72^{\circ} \mathrm{C}$ for $1 \mathrm{~min} 30 \mathrm{sec}$, followed by a final extension step at $72^{\circ} \mathrm{C}$ for $10 \mathrm{~min}$ and maintenance at $20^{\circ} \mathrm{C}$. The PCR products were resolved on a $1.0 \%$ agarose gel, visualized using Goldview II nuclear staining dyes, after which the products were cut, isolated and purified using a Qiaquick Gel Extraction kit according to manufacturer's protocol.

The VZV ORF4 tagged with the galK gene was prepared and verified as follows: $900 \mathrm{ng}$ purified VZV ORF4 galK cassette was electroporated into SW102-VZV ${ }^{\mathrm{WT}}$ BAC electrocompetent cells, and the bacteria was immediately transferred to a tube containing $1 \mathrm{ml} \mathrm{LB}$ and was incubated at $32^{\circ} \mathrm{C}$ for $1 \mathrm{~h}$ with agitation. Following centrifugation (speed in $13,000 \mathrm{x} \mathrm{g}$ for $1 \mathrm{~min}$ at room temperature), the supernatant was discarded, and the pellet was washed twice with M9 medium. The bacteria were smeared onto M63 minimal galK plates, and colony growth was observed after incubation at $32^{\circ} \mathrm{C}$ for 3 days. Two colonies were selected, and the plasmid DNA was extracted. To verify that the SW102 colonies contained the VZVORF4-galK-BAC, PCR was conducted as mentioned above for VZV ORF4 galK cassette using the extracted DNA as a template alongside the primers for ORF4 Check (Table I), and negative control using sterile water. The correct clone was named SW102-VZVORF4-galK-BAC.

The correct clone of SW102-VZVORF48-galK-BAC and SW102-VZVORF4-galK-ORF48-galK-BAC was conducted in the same way as the SW102-VZVORF4-galK-BAC protocol. 
Table I. Primers used in the present study.

Primer

Sequence $\left(5^{\prime}-3^{\prime}\right)$

Amplicon size (bp)

$\begin{array}{ll}\text { VZV ORF4 } & \\ \text { galK F } & \text { ggaagatacaggcaactgcaaacacgcaattgtcagatattttgcagccatgCCTGTTGACAATTAATCATCG } \\ \text { galK R } & \text { gtcttcacaaatagtagacacgtctgggtcggttggaattgaagcagaggcTCAGCACTGTCCTGCTCCTT } \\ \text { FKBP F } & \text { ggaagatacaggcaactgcaaacacgcaattgtcagatattttgcagccatgATGGGAGTGCAGGTGGAAAC } \\ \text { FKBP R } & \text { gtcttcacaaatagtagacacgtctgggtcggttggaattgaagcagaggcTTCCGGTTTTAGAAGCTCCAC } \\ \text { Check F } & \text { ggaagatacaggcaactgca } \\ \text { Check R } & \text { gtcttcacaaatagtagaca } \\ \text { VZV ORF48 } & \\ \text { galK F } & \text { gttgttgtgtcacgataattcagaaatacgctcggatcaccetttattatgCCTGTTGACAATTAATCATCGGCA } \\ \text { galK R } & \text { ttttggctggctgggggcttatgtcgatcctatccaatcccgatcgtgcTCAGCACTGTCCTGCTCCTT } \\ \text { FKBP F } & \text { gttgttgtgtcacgataattcagaaatacgctcggatcaccctttattatgATGGGAGTGCAGGTGGAAACC } \\ \text { FKBP R } & \text { ttttggctggctgggggcttatgtcgatcctatccaatcccgatcgtgcTTCCGGTTTTAGAAGCTCCAC } \\ \text { Check F } & \text { gcactcaaagcttttcgaag } \\ \text { Check R } & \text { acaaaagggtgctgtagacc }\end{array}$

F, forward; FKBP, FK506 binding protein; galK, galactokinase; ORF, open reading frame; R, reverse; VZV, varicella-zoster virus.

Electrocompetent cell SW102-VZVORF4-galK-BAC, SW102-VZVORF48-galK-BAC and SW102-VZVORF4-galKORF48-galK-BAC were prepared and stored at $-80^{\circ} \mathrm{C}$.

Counterselection to replace galK with desired FKBP. PCR was used to generate VZVORF4-FKBP, as follows: PCR was conducted in a $100 \mu \mathrm{l}$ volume containing $1 \mathrm{X}$ PCR buffer, $3.0 \mathrm{mM} \mathrm{MgCl} 2,10 \mu \mathrm{M}$ dNTPs, 4 units HotStar Taq DNA polymerase, $10 \mu \mathrm{M}$ VZVORF4 FKBP primer sets (Table I) and 200 ng DNA (pFKBP), using sterile water as negative control. The PCR cycling conditions were as follows: Denaturation of the template at $95^{\circ} \mathrm{C}$ for $15 \mathrm{~min}$, followed by 31 cycles at $95^{\circ} \mathrm{C}$ for $30 \mathrm{sec}, 55^{\circ} \mathrm{C}$ for $30 \mathrm{sec}$ and $72^{\circ} \mathrm{C}$ for $30 \mathrm{sec}$, followed by a final extension step at $72^{\circ} \mathrm{C}$ for $10 \mathrm{~min}$ and maintenance at $20^{\circ} \mathrm{C}$. The PCR products were resolved by $1.0 \%$ agarose gel electrophoresis, after which products were cut, isolated and purified using a purification kit.

SW102-VZVORF4-FKBP was prepared and verified as follows: $900 \mathrm{ng}$ purified VZVORF4-FKBP PCR products were electroporated into SW102-VZVORF4-galK-BAC electrocompetent cells. Following electroporation, the bacteria were allowed to recover in $1 \mathrm{ml} \mathrm{LB}$ medium at $32^{\circ} \mathrm{C}$ for $4-5 \mathrm{~h}$ with agitation. This long recovery period enriched for bacteria that only contained the desired recombined BAC, and resulted in the loss of any BAC that still contained the galK markers. The bacterial suspension was then centrifuged (speed in 13,000 x g for $1 \mathrm{~min}$ at room temperature), and the pellet was washed twice with M9 buffer. After the second wash, the pellet was resuspended in $1 \mathrm{ml} \mathrm{M} 9$ medium, and $100 \mu \mathrm{l}$ bacteria (1:100 dilution) were plated onto M63 minimal plates containing 2-deoxygalactose. The plates were incubated at $32^{\circ} \mathrm{C}$ for 3 days, after which colonies were observed. Two clones were selected, and the plasmid DNA was extracted. To verify that the SW102 colonies contained the VZVORF4-FKBP-BAC, PCR was conducted as described above for VZVORF4-FKBP using the extracted DNA as a template and the primers for ORF4 Check, negative control using VZV ${ }^{\mathrm{WT}}$ DNA as a PCR template. The correct clone was named SW102-VZVORF4-FKBP-BAC. SW102-VZVORF4-FKBP-BAC electroporation-competent cells were then prepared and stored at $-80^{\circ} \mathrm{C}$.

SW102-VZVORF48-FKBP-BAC and SW102-VZVORF4FKBP-ORF48-FKBP-BAC were obtained in the same manner as described for SW102-VZVORF4-FKBP-BAC.

Maxiprep. DNA was extracted from VZVORF4-FKBP-BAC, VZVORF48-FKBP-BAC and VZVORF4-FKBP-ORF48FKBP-BAC according to a previously published protocol (1). The BAC DNA concentration was measured, and the DNA was stored at $4^{\circ} \mathrm{C}$.

Transfection of BAC DNA and regulation of Shield1. ARPE-19 were incubated in a 6-well-plate at $37^{\circ} \mathrm{C}$ in a humidified atmosphere containing $5 \% \quad \mathrm{CO}_{2}$. Transfection was performed using VZV ${ }^{\mathrm{WT}}-\mathrm{BAC}$, VZVORF4-FKBP-BAC, VZVORF48-FKBP-BAC and VZVORF4-FKBP-ORF48-FKBP-BAC once the ARPE-19 cells reached $60 \%$ confluence.

The BAC DNA was transfected into ARPE-19 cells using the FuGene 6 transfection kit (Roche Diagnostics, Indianapolis, IN, USA), as follows: $6.0 \mu \mathrm{g}$ BAC DNA was diluted to $200 \mu \mathrm{l}$ using DMEM (without antibiotics). Concurrently, $24 \mu \mathrm{l}$ transfection reagent was diluted to $400 \mu \mathrm{l}$ with serum-free medium. The two solutions were then mixed and incubated for $20 \mathrm{~min}$ at room temperature. Subsequently, BAC DNA and transfection reagent mixtures for VZV ${ }^{\mathrm{WT}}$-BAC (335 ng/ $\left.\mu \mathrm{l}, 18 \mu \mathrm{l}\right)$, VZVORF4-FKBP-BAC (338 ng/ $\mu \mathrm{l}, 18 \mu \mathrm{l}), \mathrm{VZVORF} 48-\mathrm{FKBP}-\mathrm{BAC}(365 \mathrm{ng} / \mu \mathrm{l}, 16.5 \mu \mathrm{l})$ and VZVORF4-FKBP-ORF48-FKBP-BAC (355 ng/ $\mu \mathrm{l}, 17 \mu \mathrm{l})$ were added to ARPE-19 cells. Each transfection mixture was added to four wells of cells, of which Shield1 $(200 \mu \mathrm{M}, 2 \mu \mathrm{l})$ was added to two wells, but not to the remaining two wells. The medium was replaced $24 \mathrm{~h}$ post-transfection. Subsequently, 
the medium was changed every 2-3 days. To observe viral growth, the cells were checked every day with a fluorescence microscope.

Detection of VZVORF4-FKBP, VZVORF48-FKBP and VZVORF4-FKBP-ORF48-FKBP in transfected cells. The transfected cells were cultured using DMEM with $100 \mathrm{U} / \mathrm{ml}$ Penicillin-Streptomycin, 10\% fetal bovine serum, treated with or without Shield1, and maintained at $37^{\circ} \mathrm{C}$ in humidified atmosphere of $5 \% \mathrm{CO}_{2} / 95 \%$ air. The media were changed every 2-3 days. Then, the cells were collected after 20 days of cultivation, and total RNA was isolated using the Micro-to-Midi Total RNA Purification system kit (BioTeke Corporation) according to the manufacturer's protocol. Reverse transcription (RT) of isolated mRNA was then performed to produce double-stranded DNA. The cDNA of transfected cells was verified by PCR (same as the VZVORF4-FKBP PCR protocol) using ORF4 and ORF48 Check primers. VZV ${ }^{\mathrm{WT}}$ cDNA was used as a control.

Titering and viral growth curve analysis. Recombinant VZVORF4-FKBP, VZVORF48-FKBP and VZVORF4FKBP-ORF48-FKBP viruses were titered by infectious focus assay. Briefly, ARPE-19 cells $\left(2 \times 10^{5}\right.$ cell $\left./ \mathrm{ml}\right)$ were suspended in DMEM with $100 \mathrm{U} / \mathrm{ml}$ penicillin-streptomycin, and $10 \%$ fetal bovine serum, and treated with or without Shield1. Then, they were inoculated in 12-well plates and were mixed with serial dilutions of virus-infected ARPE-19 cells. Plaques were counted by fluorescence microscopy 3 days postinfection. Growth curve analyses were conducted based on live-cell bioluminescence. Briefly, ARPE-19 cells $\left(2 \times 10^{5}\right.$ cell $/ \mathrm{ml}$ ) were suspended in DMEM (with $100 \mathrm{U} / \mathrm{ml}$ penicillin-streptomycin) and 10\% fetal bovine serum, and treated with or without Shield1 were infected with the same amount $\left(1 \times 10^{5} \mathrm{PFU} / \mathrm{ml}\right)$ of $\mathrm{VZV}^{\mathrm{WT}}$, VZVORF4-FKBP, VZVORF48-FKBP and VZVORF4-FKBP-ORF48-FKBP viruses in 12-well plates. Each virus was used to inoculate cells in 3 wells per 12 -well plate. After $2 \mathrm{~h}$ at $37^{\circ} \mathrm{C}, 150 \mathrm{~g} / \mathrm{ml}$ D-luciferin was added to the cell culture media, and bioluminescent signals were quantified and recorded using an in vivo imaging system (Biocompare, South San Francisco, CA, USA) following incubation for $10 \mathrm{~min}$ at $37^{\circ} \mathrm{C}$. Finally, cell culture media was replaced with new cell culture media for further incubation. Measurements were repeated every $24 \mathrm{~h}$, for 7 days. Viral growth curves for each sample were thus generated.

\section{Results}

Preparation of VZV ORFs tagged with galK and FKBP. PCR was used to generate the VZV ORF4 and ORF48 galK and FKBP cassettes. Successful PCR amplification of the VZV ORF4 and ORF48 galK cassettes was confirmed by the detection of $1,400 \mathrm{bp}$ PCR products on a $1.0 \%$ agarose gel (Fig. 1A). Consistent with the expected results, $\sim 500$ bp PCR products, representing the VZV ORF4 and ORF48 FKBP cassettes (Fig. 1B), were observed on a 1.0\% agarose gel.

VerificationofVZVORF4,VZVORF48 and VZVORF4-ORF48 tagged with galK and FKBP. Two colonies were selected from
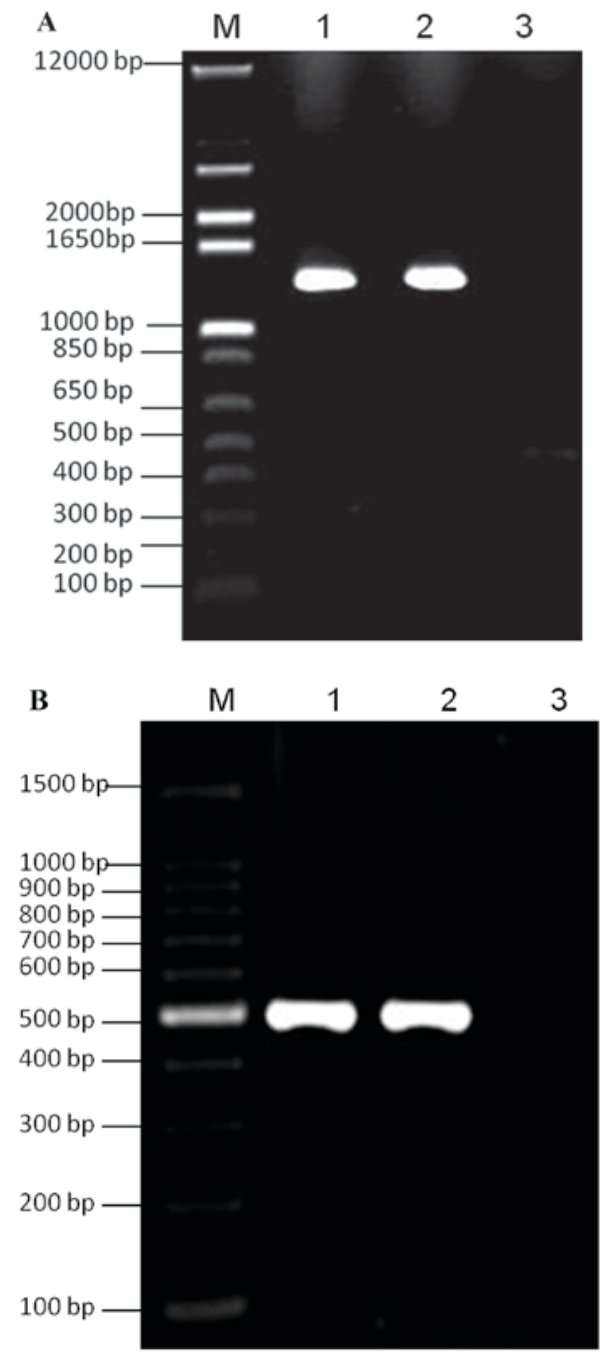

Figure 1. PCR amplification of galK and FKBP. (A) Lane M, 100 bp DNA ladder; lane 1, PCR amplification of VZV ORF4 galK cassette; lane 2, PCR amplification of VZV ORF48 galK cassette; lane 3, negative control. (B) Lane M, 100 bp DNA ladder; lane 1, PCR amplification of VZVORF4 FKBP cassette; lane 2, PCR amplification of VZV ORF48 FKBP cassette; lane 3, negative control. FKBP, FK506 binding protein; galK, galactokinase; ORF, open reading frame; PCR, polymerase chain reaction; VZV, varicella-zoster virus.

the M63 minimal galK plates following transformation of ORF4 and ORF48 galK cassettes into SW102-VZV ${ }^{\mathrm{WT}}$ BAC electrocompetent cells. Plasmid DNA was extracted and was used as a template for PCR verification of the presence of galK. As expected, 1,400 bp PCR products were detected on a $1.0 \%$ agarose gel (Fig. 2).

Counterselection was conducted to replace galK with FKBP. Two colonies were selected from the M63 minimal plates containing 2-deoxygalactose and chloramphenicol, following electroporation to generate SW102-VZVORF4-galK-BAC, SW102-VZVORF48-galK-BAC and SW102-VZVORF4-galKORF48-galK-BAC electrocompetent cells. Plasmid DNA was extracted from the two selected colonies, and used as a template for PCR verification. Consistent with the expected results, $500 \mathrm{bp}$ PCR products were detected on a $1.0 \%$ agarose gel (Fig. 3). The clones were named SW102-VZVORF4-FKBP-BAC, SW102-VZVORF48-FKBP-BAC and SW102-VZVORF4-FK BP-ORF48-FKBP-BAC. 


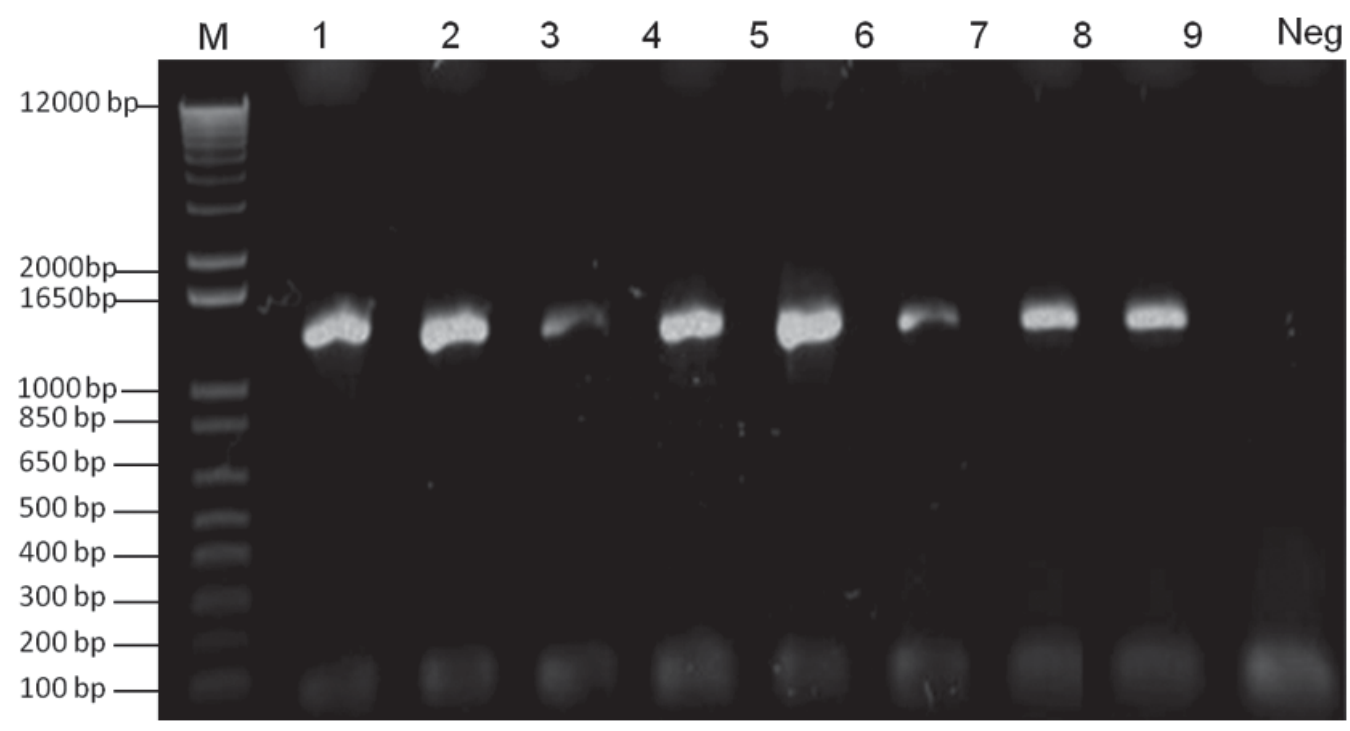

Figure 2. Verification of galK-tagged VZV ORF4 and ORF48. Lane M, $100 \mathrm{bp}$ DNA ladder; lanes 1 and 2, verification of galK-tagged ORF4 from two clones of SW102-VZVORF4-galK-BAC; lanes 3 and 4, verification of galK-tagged ORF48 from two clones of SW102-VZVORF48-galK-BAC; lanes 5-8, verification of galK-tagged ORF4 and ORF48 from four clones of SW102-VZVORF4-galK-ORF48-galK-BAC; Neg, negative control. BAC, bacterial artificial chromosome; galK, galactokinase; ORF, open reading frame; PCR, polymerase chain reaction; VZV, varicella-zoster virus.

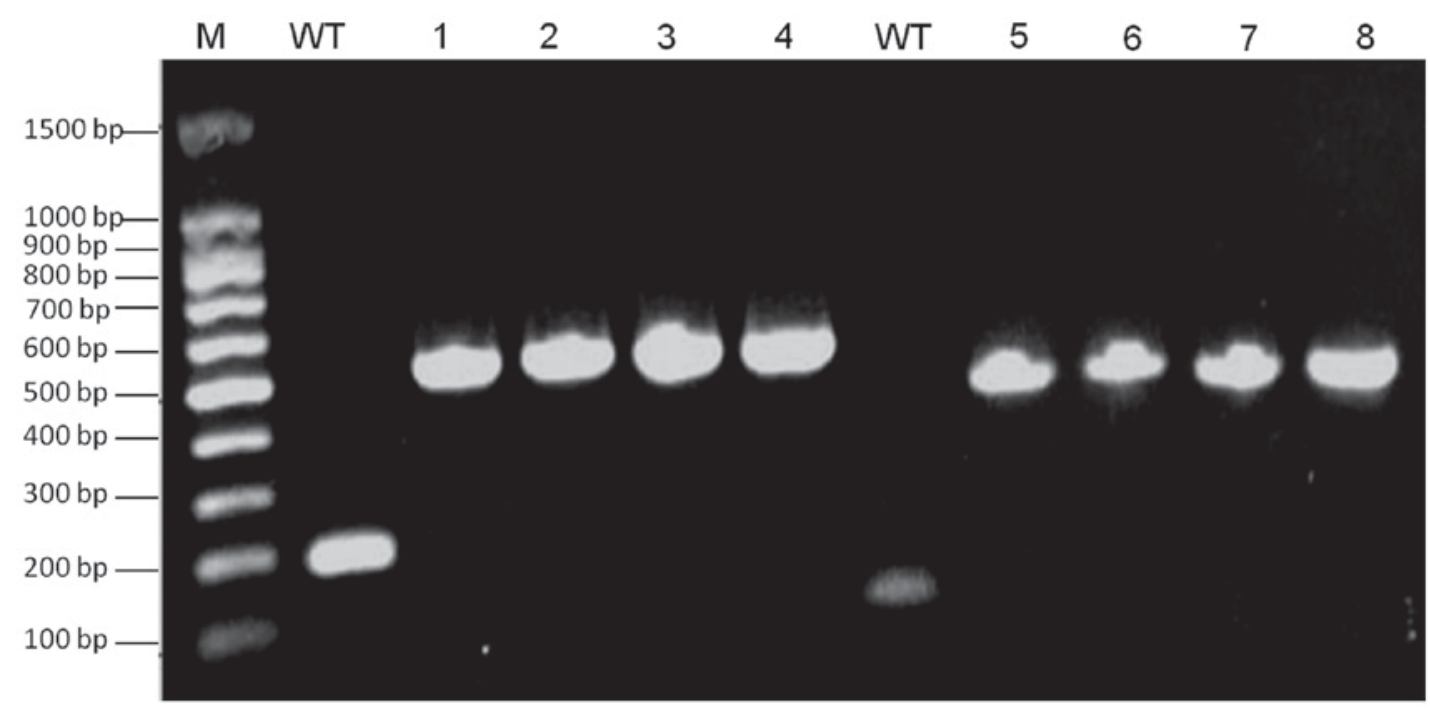

Figure 3. Verification of FKBP-tagged VZV ORF4 and ORF48. Lane M, 100 bp DNA ladder; WT, negative control using VZV ${ }^{\mathrm{WT}}$ DNA as a PCR template; lanes 1 and 2, detection of ORF48-FKBP from SW102-VZVORF48-FKBP-BAC clones; lanes 3 and 4, detection of ORF48-FKBP from SW102-VZVORF4-F KBP-ORF48-FKBP-BAC clones; lanes 5 and 6 detection of ORF4-FKBP from SW102-VZVORF4-FKBP-BAC clones; lanes 7 and 8, detection ORF4-FKBP from SW102-VZVORF4-FKBP-ORF48-FKBP-BAC clones. BAC, bacterial artificial chromosome; FKBP, FK506 binding protein; ORF, open reading frame; PCR, polymerase chain reaction; VZV, varicella-zoster virus; WT, wild type.

Transfection. Plasmid DNA from SW102-VZVORF4FKBP-BAC, SW102-VZVORF48-FKBP-BAC and SW102VZVORF4-FKBP-ORF48-FKBP-BAC was transfected into ARPE-19 cells (Fig. 4). A total of 3 days post-transfection, green fluorescence, indicating viral plaques, was observed in cells with and without Shield1. After a longer incubation period, more fluorescence plaques were observed in cells transfected with SW102-VZVORF4-FKBP-O RF48-FKBP-BAC and treated with Shield1 (Fig. 4A), and in cells transfected with VZV ${ }^{\mathrm{WT}}-\mathrm{BAC}$ and treated with or without Sheild1 (Fig. 4C and D), and in cells transfected with SW102-VZVORF4-FKBP-BAC and SW102-VZVORF48-FKBP-BAC and treated with or without
Shield1 (data not shown). Conversely, weak fluorescence was observed in cells transfected with SW102-VZVORF4-FKBPORF48-FKBP-BAC DNA without Shield1 (Fig. 4B).

Verification of FKBP from transfected cells by $R T$-PCR. Transfected cells were collected and underwent RNA extraction, after which RT-PCR was conducted. A $\sim 500$ bp product was observed in cells transfected with SW102-VZVORF4-FKBP-BAC and SW102-VZVORF48-FKBP-BAC, with or without Shield1 treatment, and in cells transfected with SW102-VZVORF4-FK BP-ORF48-FKBP-BAC and treated with Shield1 (Fig. 5). The results of Fig. 5 demonstrated that VZV ${ }^{\mathrm{WT}}$, VZVORF4-FKBP 

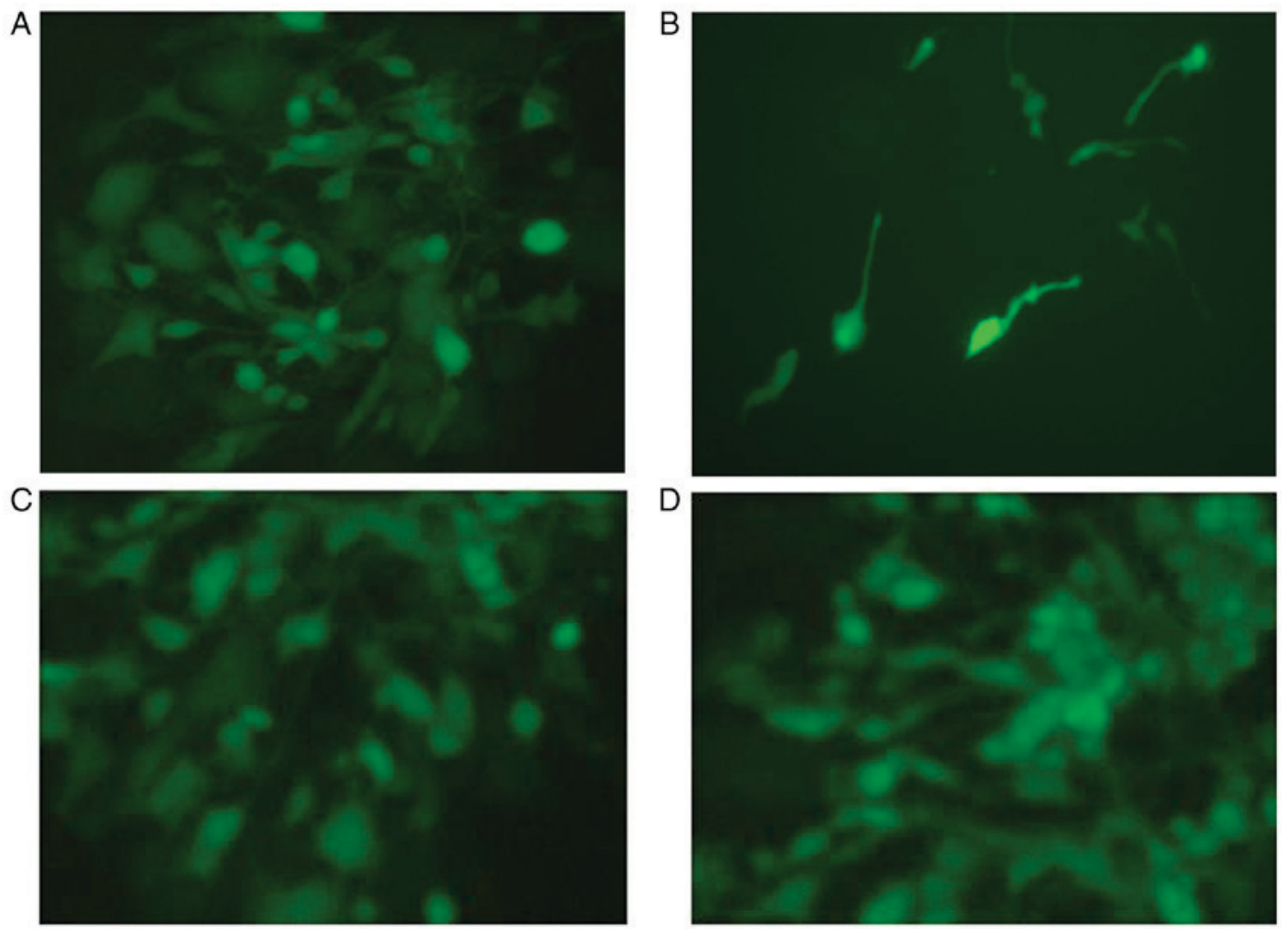

Figure 4. Viral replication visualized under fluorescence microscopy (magnification, x400). (A) Viral growth was observed 20 days post-transfection of ARPE-19 cells with SW102-VZVORF4-FKBP-ORF48-FKBP-BAC and treatment with Shield1. Numerous green viral plaques were visualized under fluorescence microscopy. (B) Viral growth was observed 20 days post-transfection of ARPE-19 cells with SW102-VZVORF4-FKBP-ORF48-FKBP-BAC without Shield1 treatment. Few green viral plaques were visualized under fluorescence microscopy. (C) Viral growth was observed 20 days post-transfection of ARPE-19 cells with SW102-VZVWT with Shield1 treatment. (D) Viral growth was observed 20 days post-transfection of ARPE-19 cells with SW102-VZVWT without Shield1 treatment. BAC, bacterial artificial chromosome; FKBP, FK506 binding protein; ORF, open reading frame; VZV, varicella-zoster virus; WT, wild type.

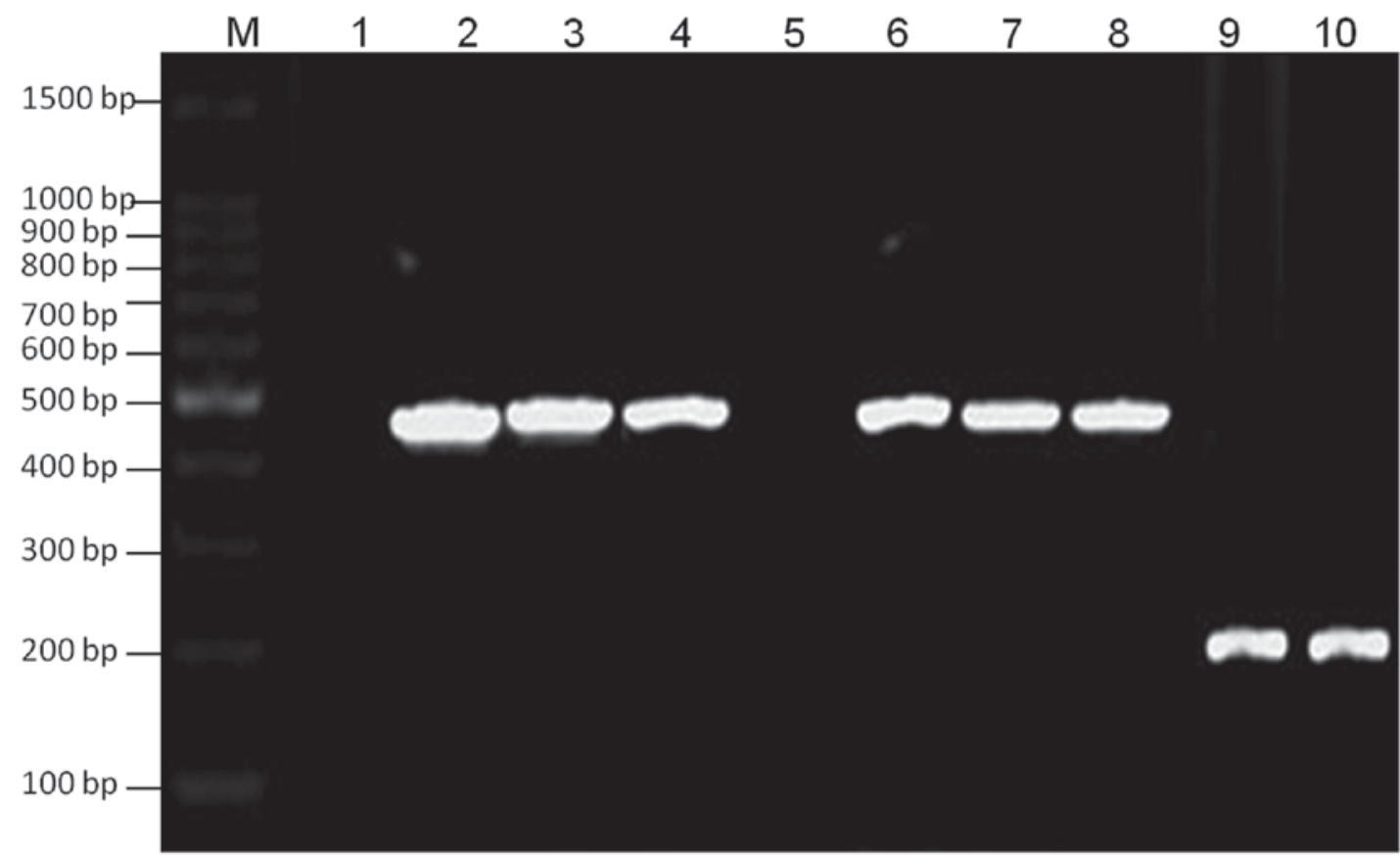

Figure 5. Verification of FKBP from transfected cells by reverse transcription polymerase chain reaction. Lanes 1 and 5, verification of VZVORF4-FKBP and VZVORF48-FKBP from ARPE-19 cells transfected with VZVORF4-FKBP-ORF48-FKBP-BAC without Shield1 treatment, respectively; lanes 2-4, verification of VZVORF4-FKBP from ARPE-19 cells transfected with VZVORF4-FKBP-ORF48-FKBP-BAC and treated with Shield1, and from ARPE-19 cells transfected with VZVORF4-FKBP-BAC treated with or without Shield1, respectively; lanes 6-8, verification of VZVORF48-FKBP from ARPE-19 cells transfected with VZVORF4-FKBP-ORF48-FKBP-BAC and treated with Shield1, and from ARPE-19 cells transfected with VZVORF48-FKBP-BAC treated with or without Shield1, respectively; lanes 9 and 10, negative control: ARPE-19 cells transfected with VZV ${ }^{\text {WT }}$-BAC treated with or without Shield1, respectively. BAC, bacterial artificial chromosome; FKBP, FK506 binding protein; ORF, open reading frame; VZV, varicella-zoster virus; WT, wild type. 

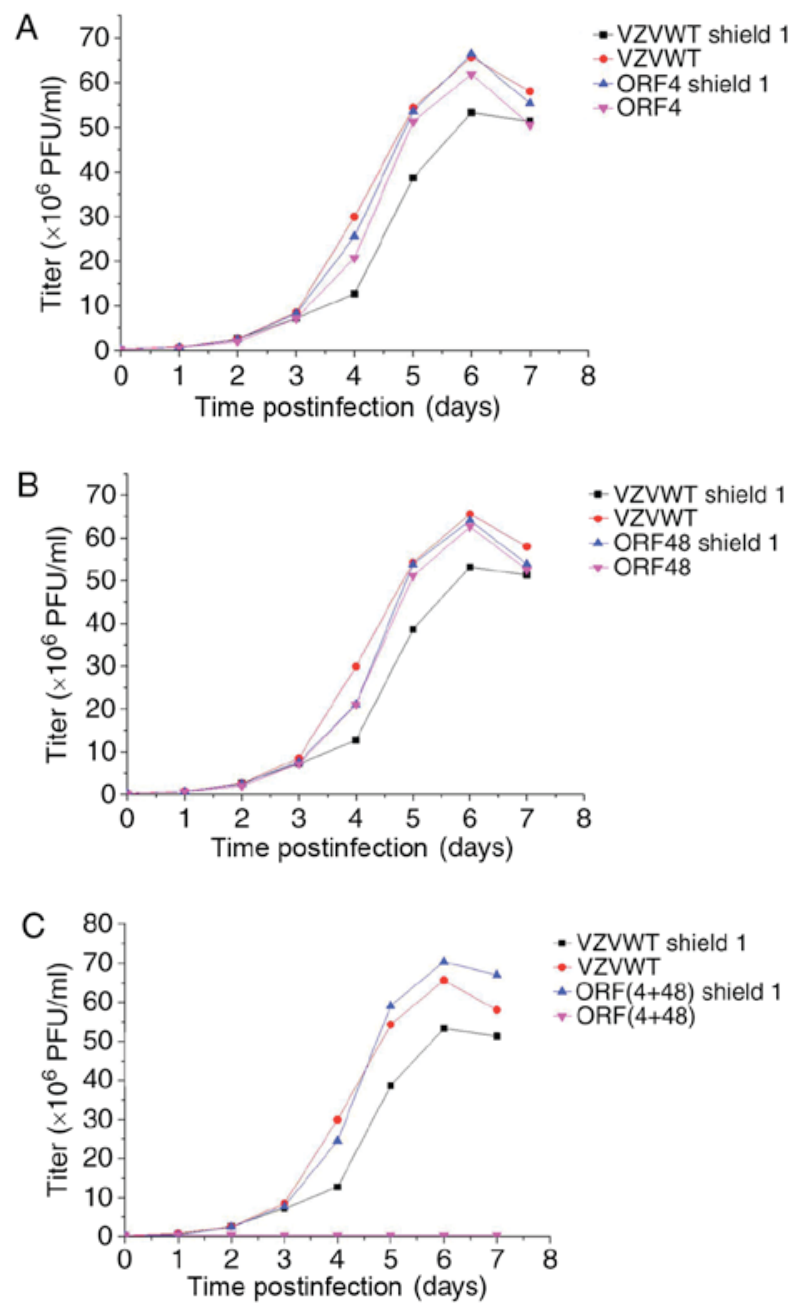

Figure 6. Growth properties of recombinant viruses determined in infected cells treated with or without Shield1. Cells were transfected with VZV ${ }^{\text {WT }}$, (A) VZVORF4-FKBP, (B) VZVORF48-FKBP and (C) VZVORF4-FKBP-ORF48-FKBP, and were treated with or without Shield1. FKBP, FK506 binding protein; ORF, open reading frame; VZV, varicella-zoster virus; WT, wild type.

and VZVORF48-FKBP may grow in infected ARPE-19 cells if the cell media is treated with or without Shield1, respectively; however, VZVORF4-FKBP-ORF48-FKBP did not grow if the cell media was treated without Shield1, and VZVORF4-FKBP-ORF48-FKBP grew if the ARPE-19 cells were treated with Shield1.

Titering and growth properties of recombinant viruses in the presence and absence of Shieldl. Each sample was tittered using an infectious focus assay, and data were used to generate a final curve (data not shown). For the bioluminescence assay, 3 wells from 12 -well plates were inoculated with the recombinant viruses, in order to measure their growth properties in the presence and absence of Shield1 $2 \mathrm{~h}$ postinfection. Measurements were repeated every $24 \mathrm{~h}$ for 7 days following addition of the reaction substrate D-luciferin to cells. Bioluminescence data were collected and analyzed to generate viral growth curves (Fig. 6A-C). The results of Fig. 6 demonstrated that the titer of the FKPB-tagged virus may be regulated by Shield1 in infected ARPE-19 cells.

\section{Discussion}

The development of BAC has been a major breakthrough in virology, as BAC clones enable large fragments of viral genomes to be cloned. BAC clones of viruses remain stable and can spread in bacterial cells; therefore, the viral genome can easily operate in bacterial cells. In addition, any required mutants can be easily and quickly generated in bacterial cells (21-23).

The ability to rapidly regulate the functions of specific proteins in living cells is a desirable tool for biological research. Banaszynski et al (20) developed a general technique to regulate the stability of the $12-\mathrm{kDa}$ FKBP protein that can be fused at either the $\mathrm{N}$ - or C-terminus when expressed in mammalian cells (24). The synthetic ligand Shield1 can bind to the destabilization domains and shield them from degradation, thus allowing fused proteins to perform their cellular functions.

Maximum stabilization typically was observed using Shield1 with achieved maximum protein levels depending on FKBP protein in live animals (25). However, FKBP protein is degraded to background levels within $2-4 \mathrm{~h}$ if Shield1 is removed. In addition, Shield1 stabilization resulted in a $>50$-fold increase in mean fluorescence intensity of yellow fluorescent protein in vitro (26). Ma et al (27) previously constructed a modified pTREX vector, the N-terminal of which expressed 3flag-destabilization domain FKBP. The vector was subsequently transfected into epimastigotes. The results demonstrated that the fusion protein was gradually degraded in the absence of Shield1; however, following addition of Shield1 to the parasites, the fusion protein once again became detectable, indicating that fusion protein expression and efficient function were regulated by Shield1 in various Trypanosoma cruzi life cycle stages.

The present study used a BAC system to clone long fragments of viral DNA, and VZVORF4-FKBP-BAC, VZVORF48-FKBP-BAC and VZVORF4-FKBP-ORF48FKBP-BAC were constructed using the homologous recombination method. A previously described method was used for FKBP tagging (20), and the ability of Shield1 to regulate protein degradation in FKBP-tagged VZV ORF4-, ORF48- and ORF4-48-transfected cells during VZV replication was studied. Human ARPE-19 cells were transfected with the recombinant virus, and the FKPB-tagged viral proteins were rapidly degraded by proteases. However, degradation of the FKPB-tagged viral proteins could be prevented by the addition of Shield1, thereby allowing viral replication in these epithelial cells. The results demonstrated that only FKBP-tagged VZV ORF4-48 proteins were regulated by Shield1 in transfected ARPE-19 cells. Conversely, FKBP-tagged VZV ORF4 and ORF48 proteins were not regulated by Shield1 during VZV replication in transfected ARPE-19 cells. These results indicated that Shield1 may regulate replication of VZVORF4-FKBP-ORF48-FKBP in infected ARPE-19 cells. In conclusion, the present study is one of few studies that aimed to determine the viral gene functions of VZV ORFs using FKBP tags, and the recombinant VZVORF4-FKBP-ORF48-FKBP has the potential of developing into a VZV vaccine, as Shield1 may regulate its replication, and lay the foundation for preventing clinical 
associated diseases. In the future, the authors of the present study will analyze the immunological effects of Shield1 regulating the replication of VZVORF4-FKBP-ORF48-FKBP in infected animals.

\section{Acknowledgements}

The present study was supported by the Project of Science and Technology for Overseas Scholars in Hebei Province (grant no. C201400559) and the Project of Hebei Education Department (grant no. ZD2016003).

\section{References}

1. Visalli MA, House BL, Selariu A, Zhu H and Visalli RJ: The varicella-zoster virus portal protein is essential for cleavage and packaging of viral DNA. J Virol 88: 7973-7986, 2014.

2. Khalil MI, Arvin A, Jones J and Ruyechan WT: A sequence within the varicella-zoster virus (VZV) OriS is a negative regulator of DNA replication and is bound by a protein complex containing the VZV ORF29 protein. J Virol 85: 12188-12200, 2011.

3. Berarducci B, Rajamani J, Zerboni L, Che X, Sommer M and Arvin AM: Functions of the unique $\mathrm{N}$-terminal region of glycoprotein $\mathrm{E}$ in the pathogenesis of varicella-zoster virus infection. Proc Natl Acad Sci USA 107: 282-287, 2010.

4. Zhang Z, Selariu A, Warden C, Huang G, Huang Y, Zaccheus O, Cheng T, Xia N and Zhu H: Genome-wide mutagenesis reveals that ORF7 is a novel VZV skin-tropic factor. PLoS Pathog 6: e1000971, 2010

5. Zhang Z, Huang $\mathrm{Y}$ and Zhu $\mathrm{H}$ : An efficient protocol for VZV BAC-based mutagenesis. Methods Mol Biol 634: 75-86, 2010.

6. Zhang Z, Huang Y and Zhu H: A highly efficient protocol of generating and analyzing VZV ORF deletion mutants based on a newly developed luciferase VZV BAC system. J Virol Methods 148: 197-204, 2008

7. Zhang Z, Rowe J, Wang W, Sommer M, Arvin A, Moffat J and Zhu $\mathrm{H}$ : Genetic analysis of varicella-zoster virus ORF0 to ORF4 by use of a novel luciferase bacterial artificial chromosome system. J Virol 81: 9024-9033, 2007.

8. Takahashi M, Asano Y, Kamiya H, Baba K, Ozaki T, Otsuka T and Yamanishi K: Development of varicella vaccine. J Infect Dis 197 (Suppl 2): S41-S44, 2008.

9. Arvin AM: Varicella-zoster virus. Clin Microbiol Rev 9: 361-381, 1996.

10. Cohen JI: Varicella-zoster vaccine virus: Evolution in action. Proc Natl Acad Sci USA 104: 7-8, 2007.

11. Centers for Disease Control and Prevention (CDC): Decline in annual incidence of varicella-selected states, 1990-2001. MMWR Morb Mortal Wkly Rep 52: 884-885, 2003.

12. Agopian A, Lopez A, Wilson D, Peralta V, El Amin AN and Bialek S: Varicella hospitalizations in Los Angeles during the varicella vaccination era, 2003-2011: Are they preventable? Vaccine 32: 5353-5356, 2014
13. Baxter R, Tran TN, Ray P, Lewis E, Fireman B, Black S, Shinefield HR, Coplan PM and Saddier P: Impact of vaccination on the epidemiology of varicella: 1995-2009. Pediatrics 134: 24-30, 2014.

14. Galil K, Lee B, Strine T, Carraher C, Baughman AL, Eaton M, Montero J and Seward J: Outbreak of varicella at a day-care center despite vaccination. N Engl J Med 347: 1909-1915, 2002.

15. Gan L, Wang M, Yang S, Gershon AA and Chen JJ: Transmission of varicella vaccine virus to a non-family member in China. Vaccine 29: 2015-2017, 2011.

16. Oxman MN, Levin MJ, Johnson GR, Schmader KE, Straus SE, Gelb LD, Arbeit RD, Simberkoff MS, Gershon AA, Davis LE, et al: A vaccine to prevent herpes zoster and postherpetic neuralgia in older adults. N Engl J Med 352: 2271-2284, 2005.

17. Das S, Ortiz DA, Gurczynski SJ, Khan F and Pellett PE: Identification of human cytomegalovirus genes important for biogenesis of the cytoplasmic virion assembly complex. J Virol 88: 9086-9099, 2014.

18. Maetzig T,Kuehle J,Schwarzer A, Turan S, Rothe M,Chaturvedi A, Morgan M, Ha TC, Heuser M, Hammerschmidt W, et al: All-in-One inducible lentiviral vector systems based on drug controlled FLP recombinase. Biomaterials 35: 4345-4356, 2014.

19. Perng YC, Qian Z, Fehr AR, Xuan B and Yu D: The human cytomegalovirus gene UL79 is required for the accumulation of late viral transcripts. J Virol 85: 4841-4852, 2011.

20. Banaszynski LA, Chen LC, Maynard-Smith LA, Ooi AG and Wandless TJ: A rapid, reversible, and tunable method to regulate protein function in living cells using synthetic small molecules. Cell 126: 995-1004, 2006.

21. Murphy E, Yu D, Grimwood J, Schmutz J, Dickson M, Jarvis MA, Hahn G, Nelson JA, Myers RM and Shenk TE: Coding potential of laboratory and clinical strains of human cytomegalovirus. Proc Natl Acad Sci USA 100: 14976-14981, 2003.

22. Warden C, Tang Q and Zhu H: Herpesvirus BACs: Past, present, and future. J Biomed Biotechnol 2011: 124595, 2011.

23. Yu D, Silva MC and Shenk T: Functional map of human cytomegalovirus AD169 defined by global mutational analysis. Proc Natl Acad Sci USA 100: 12396-12401, 2003.

24. Bonger KM, Chen LC, Liu CW and Wandless TJ: Small molecule displacement of a cryptic degron causes conditional protein degradation. Nat Chem Biol 7: 531-537, 2011.

25. Banaszynski LA, Sellmyer MA, Contag CH, Wandless TJ and Thorne SH: Chemical control of protein stability and function in living mice. Nat Med 14: 1123-1127, 2008.

26. Sellmyer MA, Thorne SH, Banaszynski LA, Contag $\mathrm{CH}$ and Wandless TJ: A general method for conditional regulation of protein stability in living animals. Cold Spring Harb Protoc 2009: pdb.prot5173, 2009.

27. Ma YF, Weiss LM and Huang H: A method for rapid regulation of protein expression in Trypanosoma cruzi. Int J Parasitol 42: 33-37, 2012.

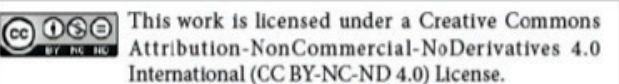

